\title{
DEVELOPING ON-FARM IRRIGATION SCHEMES FOR CURRENT AND FUTURE CLIMATE CONDITIONS ON THE WESTERN BANK OF LAKE NASSER
}

\author{
S. M. Attaher *
}

\begin{abstract}
The agricultural region in the western bank of Lake Nasser is one of the new promising agricultural settlements, which has the advantage of early-season production of several high quality cash crops. The agriculture production in this region is fully-irrigated, and constrained by sever environmental, biophysical and socio- economical conditions. Moreover, farmers have been facing several additional challenges in irrigation management due to lack of knowledge of the best practices.

The aim of this study is to evaluate the current farmers' irrigation schemes in terms of water productivity. The study examined some possible irrigation schemes in order to improve water productivity with minimum irrigation requirement and to cope with projected water shortage and temperature increase induced by climate change. The study is based on modeling approach utilizing the FAO crop model "AquaCrop" on drip irrigated tomato. It was performed (i) to calibrate AquaCrop via two field trials at two seasons, (ii) to observe and evaluate the current farmers' irrigation schemes based on fixed application frequency, and (iii) to evaluate six irrigation schemes under current and future climate conditions. The evaluated schemes included different combinations between net irrigation application and deficit practices at two levels of $80 \%$ and $60 \%$ of net water requirements, under current and future climate conditions, based on the change in irrigation application and water productivity. The results demonstrated that the combination of deficit irrigation levels and irrigation scheduling could improve tomato water productivity to the optimal level determined under the current study conditions $\left(2.4 \mathrm{~kg} / \mathrm{m}^{3}\right)$, especially when deficit levels of 80 and $60 \%$ applied at both early and late stages of crop growth stages. These schemes could present acceptable adaptation options with the projected temperature increase due to climate change.
\end{abstract}

\footnotetext{
*Researcher, Agricultural Engineering Research Institute (AEnRI), Agricultural Research Center (ARC)
} 


\section{INTRODUCTION}

The overall objective of effective on-farm irrigation management
is to maximize crop yield per each unit of applied water.
Projected future temperature rises under climate change are likely to reduce the productivity of the major crops, and increase its water requirements, thereby directly decreasing crop water use efficiency. Global warming is projected to add more pressures over the Egyptian onfarm irrigation system (Attaher et al., 2006). Therefore, developing adaptation schemes for on-farm irrigation system in Egypt become one of the high national priorities. While, the vulnerability of on-farm irrigation in Egyptian agricultural regions and the acceptable adaptation measures varies according to the local regional conditions.

The agricultural region in the western bank of Lake Nasser, which located in the southern part of the River Nile in Egypt, is one of the new promising and remote agricultural settlements. The region is characterized by hyper aridity and extreme hot climate. The government of Egypt is planning to resettle one million farmers around Lake Nasser by 2017 (CDS, 2007). Despite the remote location of this area, it has the advantage of early season production for several cash-crops, with high quality. The agricultural production in this region is fully-irrigated, and constrained by sever hot and arid climate, low soil fertility, labor unavailability, long distance from the markets, and high cost of production inputs. Agricultural production in this region could be very risky from the environmental prospective that the agriculture activates is very close to Lake Nasser; the strategic national water reservoir of Egypt. The farmers are tending to increase the irrigation-water, including chemicals, as practices to overcome sever environmental condition, which is projected to increase in the future. Under the current national water management scheme, water share for agriculture in this region is subject to reduction, as a national policy to protect Lake Nasser. Moreover, the irrigation time for each village is limited by certain hours per day, as the pumping energy is offered to the farmers as a type of social encouragement, which is limiting the irrigation practices beyond the actual irrigation requirements. 
FAO has been developing a yield-response to water model, "AquaCrop", which simulates attainable yields of the major crops (Steduto et al., 2008). As compared to other crop models, AquaCrop has a significantly smaller number of parameters and a better balance between simplicity, accuracy and robustness. Root zone water content is simulated by keeping track of incoming and outgoing water fluxes at its boundaries, considering the soil as a water storage reservoir with different layers. Instead of leaf area index, AquaCrop uses canopy ground cover. Canopy development, stomatal conductance, canopy senescence and harvest index are the key physiological crop responses to water stress. Evapotranspiration is simulated as crop transpiration and soil evaporation and the daily transpiration is used to derive the daily biomass gain via the normalized biomass water productivity of the crop. The normalization is for reference evapotranspiration and $\mathrm{CO}_{2}$ concentration to make the model applicable to diverse locations and seasons, including future climate scenarios. AquaCrop accommodates different water management systems, including rainfed agriculture and supplemental, deficit, and full irrigation.

The objective of this study is to evaluate the current farmers' irrigation schemes in terms of water productivity and irrigation-water use. The study also examined some possible irrigation schemes in order to improve water productivity with minimum irrigation water application, and to cope with projected water shortage and temperature increase projected under climate change.

\section{MATERIALS AND METHODS}

The study is based on modeling approach using the FAO crop model "AquaCrop" (Steduto et al., 2008) on "drip irrigated tomatoes" as important crop of the crop pattern of western bank of Lake Nasser. This was performed through three steps as: (i) primary calibration of the default tomato file in AquaCrop, (ii) observation and evaluation of the current farmers' irrigation schemes, and (iii) evaluate some possible irrigation schemes under current and future climate conditions.

To start with calibration, two field trials were conducted in two consequence seasons, at two reclamation villages of Kalabsha and Garf 
Hussein, located at western bank of Lake Nasser. For all trials, tomato crop (Lycopersicon esculentum, Adora cultivar) was manual transplanted at the middle of November, with $0.30 \mathrm{~m}$ between plants inter-row and $1.20 \mathrm{~m}$ between plant rows. The soil texture was sand, which had 13.3 vol. \% field capacity and 6 vol. \% wilting point. Drip irrigation system was used with line-source emitter of $0.3 \mathrm{~m}$ spacing and $4 \mathrm{~L} / \mathrm{h}$ discharge. Irrigation water-requirements and scheduling were calculated by using "CropWat" FAO model (Smith, 1992), according to the daily weather data collected from Aswan weather station located at $23.97^{\circ} \mathrm{N}$ latitude, $32.78^{\circ}$ E longitude and $199 \mathrm{~m}$ altitude. The crop daily management practices were set in order to avoid water and fertility stress and limitations, while the initial water conditions of the fields was at about field capacity. The development of crop canopy expansion and root depth were recorded during the trails, while the total tomato yield per unit area, fresh and dry matter of the fruits and the plant were determined at the end of the season. At the same time, Irrigation applications, irrigation time and total tomato yield were the main parameters, for about 13 farmers from the same villages, in order to determine the farmers' irrigation schemes.

Based on the calibration procedure, AquaCrop was used to evaluate six irrigation schemes under current and future climate conditions. Two schemes of farmers' actual irrigation practices (P1 and P2) were the first two evaluation cases, whereas, the other evaluated cases were; (i) OP1: irrigation schedule based on net irrigation requirement at depletion 50\% of readily available water (RAW), (ii) OP2: irrigation schedule based on $75 \%$ depletion of RAW at initial stage, $50 \%$ depletion of RAW at development and mid season stages, and $75 \%$ depletion of RAW at maturity stage, (iii) OP3: two deficit irrigation levels of $80 \%$ and $60 \%$ of actual water-requirements, at all crop growth stages, and finally (iv) OP4: two deficit irrigation levels of $80 \%$ and $60 \%$ of actual waterrequirements, at initial and maturity stages only.

Five years average of daily weather data of Aswan weather station was used to represent the current climate. Air temperature raise was the climatic factor used in the evaluation procedure referring to future climate change, where $\mathrm{CO}_{2}$ response is not yet finalized in AquaCrop, 
and adjustments are still needed. The Maximum and the minimum monthly values of air temperature changes of Aswan were determined from a downscaled implication of IPCC SRES scenarios (IPCC, 2000) using HadCM3 GCM climate model up to year 2100 (DDC, 2010). The current and the future $\mathrm{ET}_{\mathrm{o}}$ values were determined by using $\mathrm{FAO} \mathrm{ET}_{\mathrm{o}}$ Calculator software (Raes, 2009). In climate change simulations, the impact of air temperature increase was assessed basically on the net irrigation requirements, where the impact on the crop biomass production and the harvest index is not yet well-calibrated under the local conditions of the current study. Water productivity [WP] was calculated by using the following equation:

$$
\text { Water productivity }=\frac{\text { actual crop production }[\mathrm{kg}]}{\text { actual irrigation application }\left[\mathrm{m}^{3}\right]}
$$

\section{RESULTS AND DISCUSSION}

\section{The primary calibration of the model}

In the default crop file of tomato in AquaCrop the length of the crop life was 110 days, whereas, 150-180 days are the observed length of the winter tomatoes (October/ November) cultivars usually cultivated in Upper Egypt. Because of the extreme hot weather of the Upper Egypt, tomato is usually cultivated at the middle of November. Table 1 shows the actual crop growth and development indicators observed from the field trials. These parameters with the actual biomass and yield were used to calibrate the model under each trial. As shown in Fig.1, both crop biomass and yield for most trials were slightly overestimated, when the actual development parameters of each trial were used. Using the average values of the development parameters for all calibration trials provided the best fit for all trials.

\section{Assessing and evaluating farmers' irrigation schemes}

Two irrigation schemes were usualy applied by the farmers in western bank of Lake Nasser. Generally, the farmers use the application time instead of application volume or depth in all irrigation schemes, with 4 $\mathrm{L} / \mathrm{h}$ drippers, which gave about $9 \mathrm{~mm} / \mathrm{h}$. The first farmers' irrigation 
scheme (P1) is starting the season with long application time, up to 45 minutes per day after the transplanting, then the application time start to decrease gradually, to reach about 15 minutes per day by the end of season. The observed average yield of the winter tomato under P1 is about 10 ton/ha (4.2 ton/fed), with total irrigation application of about $550 \mathrm{~mm}$, and water productivity (WP) of about $2.2 \mathrm{~kg} / \mathrm{m}^{3}$.

The second farmers' irrigation scheme (P2) is start the season by small application time of about 10-15 minutes per day, with gradual increase in application time to reach 30 minutes per day at the flowering and fruit development phases, and to decrease once more at the maturity and late season phases, of about 20-15 minute per day by the end of the season.

The average observed yield under $\mathrm{P} 1$ is about 9 ton/ha, with total irrigation of about $420 \mathrm{~mm}$, and WP of about $2 \mathrm{~kg} / \mathrm{m}^{3}$. Reference to the model evaluation, both $\mathrm{P} 1$ and $\mathrm{P} 2$ induce biomass and yield reduction due to stomatal closure and early senescence, reducing both harvest index (HI) and WP.

Table (1): Actual crop growth and development indicators observed from the field trials, used in AquaCrop calibration to local conditions of western bank of Lake Nasser

\begin{tabular}{|l|c|c|c|c|c|}
\hline & \multicolumn{2}{|c|}{ Kalabsha } & \multicolumn{2}{c|}{ Garf Hussein } & \multirow{2}{*}{ Average } \\
\cline { 2 - 5 } & $\begin{array}{c}\text { Season } \\
1\end{array}$ & $\begin{array}{c}\text { Season } \\
2\end{array}$ & $\begin{array}{c}\text { Season } \\
1\end{array}$ & $\begin{array}{c}\text { Season } \\
2\end{array}$ & \\
\hline Number of days from & & & & & \\
transplanting to: & & & & & \\
$\quad$ a- Recovery & 5 & 6 & 6 & 7 & 6 \\
b- Full canopy & 77 & 72 & 81 & 79 & 77 \\
c- Senescence & 137 & 129 & 135 & 142 & 136 \\
e- Maturity & 163 & 158 & 171 & 168 & 165 \\
f- Flowering & 43 & 48 & 49 & 41 & 45 \\
g- Maximum root & 59 & 51 & 62 & 52 & 56 \\
depth & & & & & \\
\hline Duration of flowering & 51 & 47 & 57 & 52 & 52 \\
\hline
\end{tabular}



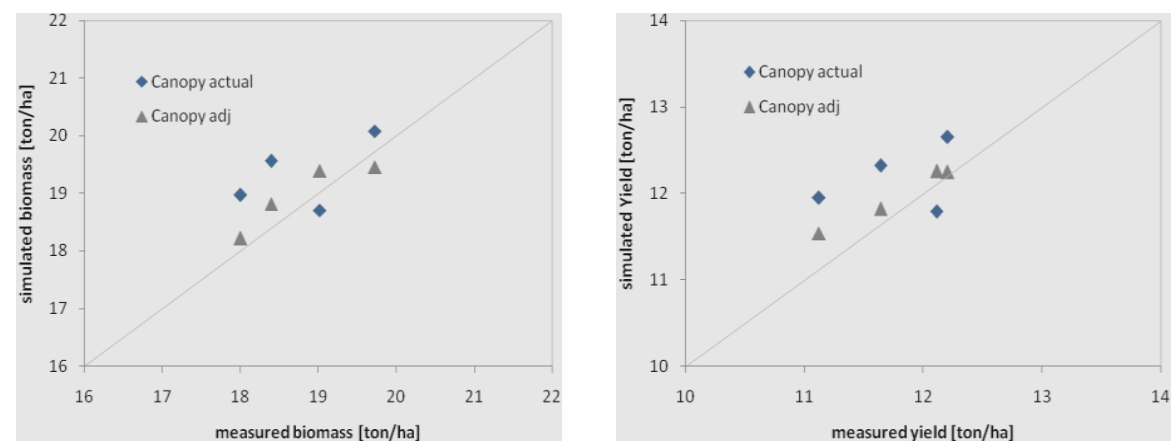

Fig. 1: AquaCrop primery calliberation: the effect of using actual crop development parameter of each trial (canopy actual), and the average development parameter of each trail (canopy adj), on actual and simulated biomass [ton/ha] and yield [ton/ha] of the tomato crop.

Under arid and semi-arid conditions, the balance between irrigation application and crop yield is highly recommended, and could be achieved by selecting the irrigation scheme that result in the minimum irrigation application, and obtain high WP compared with the optimal conditions. Fig. 2 shows the effect of the evaluated schemes on the total irrigation application and WP, at both current and future climate conditions. This figure shows that OP3_60\% scheme had the lowest irrigation application under all climate conditions, and it had the lowest WP too. Even thought, it still could be one of the possible options to cope with the sever water shortage conditions to save about $40 \%$ irrigation water, if the yield reduction accepted.

Indeed, applying deficit irrigation at both early and late stages of crop development could have a negative impact on canopy expansion and early senescence. While this practice could obtain the required balance between irrigation application and WP, with lower levels of crop reduction compared to full season deficit practice. This could be observed through OP4 $60 \& 80 \%$ schemes. Additionally, this practice helps in achieving almost the same levels of WP at higher levels of deficit application, which sustain more water saving. Furthermore, obtaining high WP could not only achieved by applying net irrigation application, different combinations between net irrigation application and deficit practices could obtain the same levels of WP with less water.

Generally, applying less irrigation has a favorable positive effect due to reduction of irrigation energy consumption and total production cost. Under western Lake Nasser, the reduction in energy cost is more 
pronounced to the farmers than the increase in crop yield. The relation between Irrigation application and WP of the evaluated schemes is almost has the same trend under current and future climate conditions.

The increase in air temperature had negative impacts on both irrigation application and WP for all schemes (Fig. 2). It's clear that the higher temperature increase, the higher irrigation application. Whereas, the temperature impact on WP due to heat and water stress responses, did not well-calibrated in the current study, and adjustments are still needed. Therefore, most schemes have the same trend of the current climate conditions with higher irrigation applications and lower WPs. OP1 was an exception of the trend under temperature increase, that both OP1 and OP3-60\% had the lowest WP, while OP1 had the highest irrigation application among all evaluated schemes, under temperature raise maximum and minimum levels.
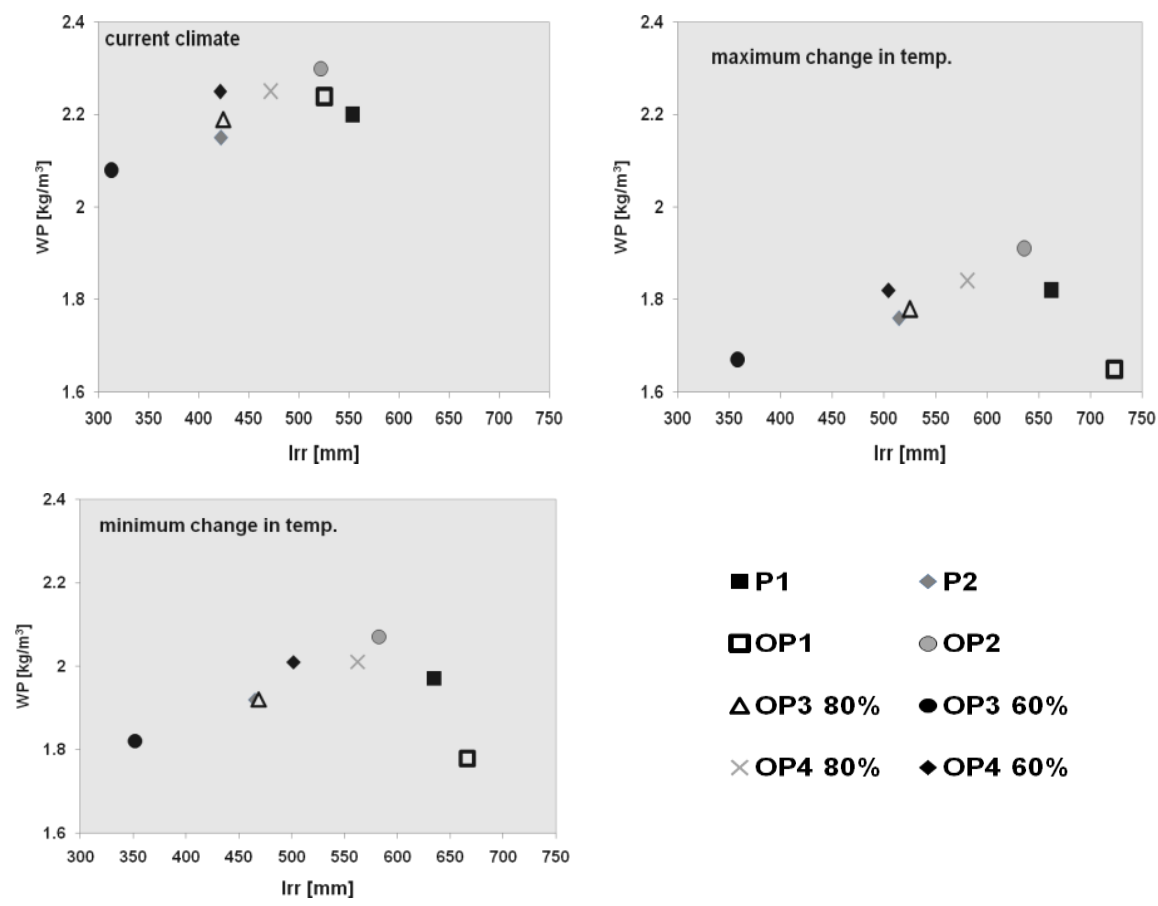

Figure (2) shows the effect of the evaluated schemes on the total irrigation application [Irr] and WP, at both current and future climate conditions.

\section{CONCLUSIONS}

Under arid climate and water shortage conditions, the balance between crop product and the irrigation requirements, is essential parameter controlling the agricultural production system. 
The results indicated that the good management (combination between deficit irrigation levels and irrigation scheduling) could improve the water productivity to the optimal level $\left(2.4 \mathrm{~kg} / \mathrm{m}^{3}\right)$, especially when deficit levels of 80 and $60 \%$ applied at the both early and late stages of crop development. This type of schemes could present acceptable adaptation options with the projected temperature increase due to climate change.

This study includes a simplified evaluation of some irrigation schemes by using AquaCrop under climate change, in terms of temperature increase only. The results included here should be considered with carful, that the heat and water stresses response to WP under climate change, did not well-calibrated, and this level of calibration will proceeded in further work.

\section{ACKNOWLEDGMENT}

The research reported in this paper was done under the joint project of "assessing climate change impacts on the remote rural communities in west Lake Nasser region- Aswan", under coordination of Center of Development Services (CDS)- Near East Foundation, IDRC.

\section{REFERENCES}

Attaher, S. M.; M. A., Medany; A.A. Abdel Aziz and A. El-Gindy (2006). Irrigation- Water Demands under Current and Future Climate Conditions in Egypt, Misr J. of Agric. Eng., 23(4): 1077-1089.

CDS (2007). Final report the Eco-health assessment; "towards a sustainable livelihoods strategy of West Lake Nasser" project; CoPEH-MENA fund with the Center for Development Services (CDS); Egypt.

DDC (2010). Climate models database. Data Distribution Center.

Intergovernmental Panel on Climate Change (IPCC). http://ipccdata.org

IPCC (2000). IPCC Special Report of Emissions Scenarios (SRES). A Special Report of Working Group III. of the Intergovernmental Panel on Climate Change (IPCC), Cambridge Univ. Press, Cambridge, UK. pp 570

Raes, D. (2009). The ETo Calculator, Reference Manual, Food and Agriculture Organization of the United Nations, Land and Water Division, FAO, Via delle Terme di Caracalla, 00153 Rome, Italy 
Smith, M. (1992). CROPWAT, a computer program for irrigation planning and management, Food and Agriculture Organization (FAO), Irrigation and Drainage Paper 46, Rome, Italy.

Steduto, P.;D., Raes; T. C., Hsiao; E., Fereres; L., Heng; G., Izzi and J., Hoogeveen (2008). AquaCrop: a new model for crop prediction under water deficit conditions, Options Mediterranean's, Series A, No. 80.

\section{الملخص العربيى}

\section{إستحداث أنماط للرى الحقلى للظروف المناخية الحالية و المستقبلية للضفة منة

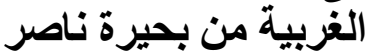 \\ *مر محمد الطاهر}

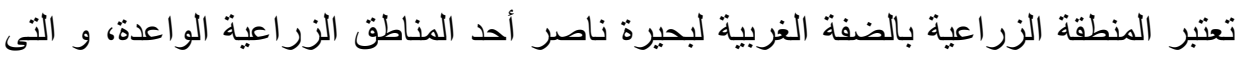

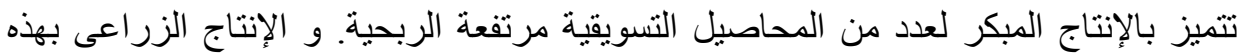

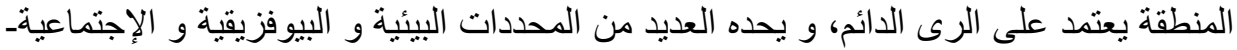

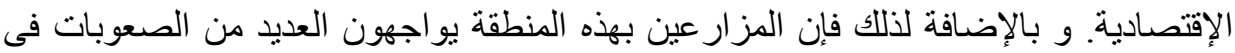

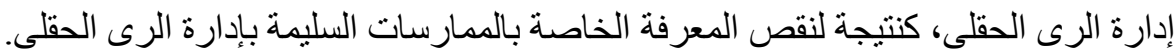

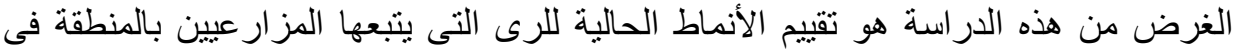

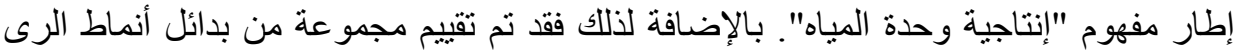

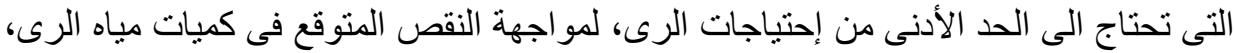

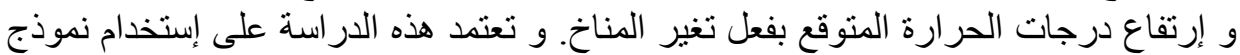

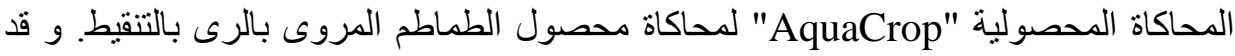
تم تنفيذ الدراسة فى ثلاث خطوات تشمل : (أ) إستخدام بيانات تجربتين حقليتين فى موسمين

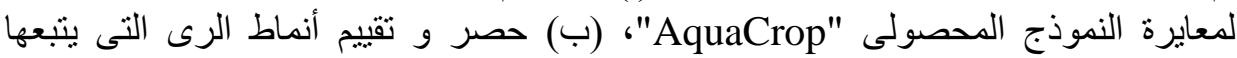

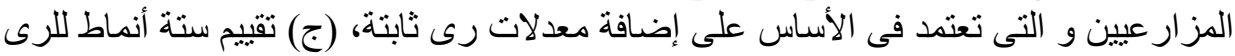
تحت ظروف المناخ الحالية و المستقبلية. و أنماط الرى التى تم تقييمها تضمنت تباديل الإيل مختلفة

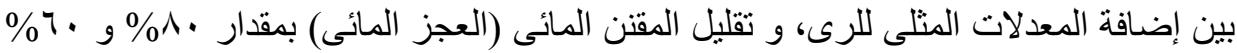
من المقنن القياسى، تحت ظروف المناخ الحالية و المستقبلية. و قد تم المقارنة بين البدائل بناء المئل على التغير فى "إنتاجية وحدة المياه" و قد أوضحت نتائج المحاكاة أن الدمج بين مستويات العجز العياه المائى و جدولة الرىى قد تؤدى الى الى

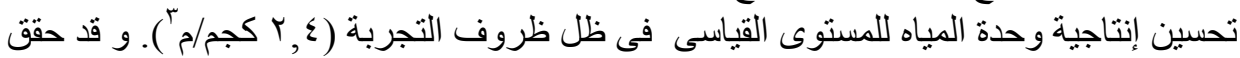

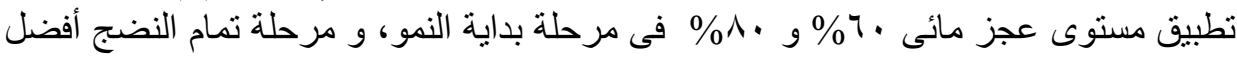

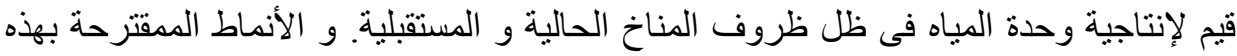

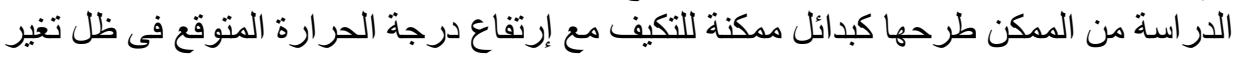

